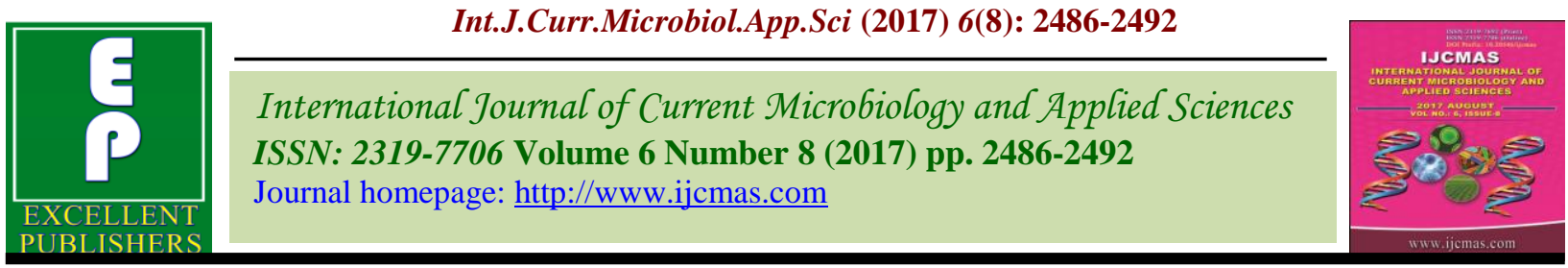

Original Research Article

https://doi.org/10.20546/ijcmas.2017.608.294

\title{
Prevalence and Knowledge of Needle Stick Injury among the Health Care Workers in a Tertiary Care Hospital Solan H.P, India
}

\author{
Amisha Sharma, Charu Singh, Seema Solanki*, Satishkumar, \\ Priya Mehrishi and Sameer Singh Faujdar \\ *Corresponding author
}

A B S T R A C T

\begin{tabular}{|c|c|}
\hline & $\begin{array}{l}\text { NSI is a major occupational health and safety issue faced by health-care professionals } \\
\text { globally. National institute for occupational safety and health define NSIs as "injuries }\end{array}$ \\
\hline Keywords & to connect part of IV delivery system". HCW are exposed to NSI from unsafe practices \\
\hline $\begin{array}{l}\text { Needle stick } \\
\text { Injury, Health } \\
\text { care workers, Post } \\
\text { exposure } \\
\text { prophylaxis. }\end{array}$ & $\begin{array}{l}\text { such as recapping of needles, manipulating used needles, such as bending, breaking or } \\
\text { cutting hypodermic needles or passing of needles from one workers to another. (1)The } \\
\text { hazard of injury is further compounded by the high prevalence of HIV, HBV, and HCV } \\
\text { among hospitalized patients that result in infections with hepatitis B and C and HIV. } \\
\text { Health care professionals are most negligent as far as their own health is concerned. The } \\
\text { hazard of iniury is further compounded by the high prevalence of HIV. HBV, and HCV }\end{array}$ \\
\hline Article Info & among hospitalized patients that result in infections with hepatitis B and C and HIV. \\
\hline $\begin{array}{l}\text { Accepted: } \\
\text { 21 June } 2017 \\
\text { Available Online: } \\
10 \text { August } 2017\end{array}$ & $\begin{array}{l}\text { Therefore this study was conducted on } 152 \text { health care workers working in a tertiary care } \\
\text { hospital of Maharishi Markendeshwar Medical College and Hospital, Kumarhatti, Solan } \\
\text { (H.P) with the objective to determine the prevalence of NSIs among the health care } \\
\text { workers, to determine the association between NSI and selected variables such as age, } \\
\text { marital status, years in service, educational qualification and to assess the measures }\end{array}$ \\
\hline & $\begin{array}{l}\text { undertaken by the respondents after the NSI and also to determine the incidence of self- } \\
\text { reported cases of needle stick and sharp instruments (NSI). }(2,3)\end{array}$ \\
\hline
\end{tabular}

\section{Introduction}

NSI is a major occupational health and safety issue faced by health-care professionals globally. National instate for occupational safety and health define NSIs as "injuries caused by needles such as hypodermic blood collection needles, IV styles and needles used to connect part of IV delivery system" (4).HCW are exposed to NSI from unsafe practices such as recapping of needles, manipulating used needles, such as bending, breaking or cutting hypodermic needles or passing of needles from one workers to another. It is revealed that the most common clinical activity to cause NSI was blood withdrawal, followed by suturing and vaccinations (5) Health care professionals are most negligent as far as their own health is concerned. Health care workers incur 2 million needle stick injuries (NSIs) per year as Needle stick injuries present the single greatest occupational hazard to medical personnel.(6) While as many as twenty blood borne pathogens can be transmitted through accidental needle sticks, the potentially life threatening are Human Immunodeficiency Virus (HIV), hepatitis B virus (HBV) and hepatitis $\mathrm{C}$ virus (HCV).(7) The World Health Organization estimates the global burden of 
disease from occupational exposure to be $40 \%$ of the hepatitis B and C infections and $2.5 \%$ of the HIV infections among HCWs as attributable to exposures at work.(8) Factors that increase risks of transmission of HIV include a deep wound, visible blood on the device, a hollow-bore blood-filled needle, use of a device to access an artery or vein and high-viral-load status of the patient. $(9,10)$. The risk of transmission through NSIs for $\mathrm{HBV}$ is $1-40 \%, \mathrm{HCV}$ is $1.8 \%$ and $\mathrm{HIV}$ is $0.3 \%$. (11) Nurses have the highest rate of NSI among health-care workers. (12) Despite their seriousness as a medical event, NSIs have been neglected, most go unreported. Therefore, this study was conducted with the objectives (a) to determine the prevalence of NSIs among the nurses, (b) to determine the association between NSI and selected variables such as age, marital status, years in service, educational qualification and (c) to assess the measures undertaken by the respondents after the NSIs. (d) to determine the incidence of self-reported cases of needle stick and sharp instruments (NSI), to know time gap between reporting and injuries, immediately what preventing action taken, the outcome of post exposure prophylaxis (PEP) for infectious injuries contaminated with HIV, $\mathrm{HBV}$ or $\mathrm{HCV}$ and to estimate under reporting of NSI in health care providers (HCW). Because needle stick injuries are often under reported, health care institutions should not interpret low reporting rate as low injury rate.

\section{Materials and Methods}

This study is a cross-sectional study conducted in a tertiary care hospital of maharishi markendeshwar medical college and hospital. Kumarhatti, solan (H.P). All the health care workers (comprising nurses, paramedic, attendants, lab technicians and housekeepers) working in the hospital were eligible to participate in the study. Those who refused to participate and those who could not be contacted for three consecutive visits were excluded from the study. As the hospital is having many sub faculty units for different specialties, therefore in our study 152 employees were assessed from all the departments of MM Medical College.

Further the employees were given pre tested and predesign self-administered questioner, that consisted questions on particulars of the respondent and questions about the needle stick event and the completely filled questionnaires were collected on the same day. After collection of data, the data was compiled and analyzed in the phased manner.

\section{Results and Discussion}

A total of 160 questioners were distributed to the consenting health care workers in MMC\&H Solan. However, 152 questioners were completely filled and returned giving a response rate of. Health care workers included nurses, paramedic, attendants, lab technicians and housekeepers.

Therefore, total 152 HWCs were analyzed according to their age, duration of their job, marital status and their knowledge in concern with NSI.

Table 1: Of the 152HCWs, maximum were (131) aged between 20-30 years. Most of them were female (132), unmarried with the maximum, higher qualification of GNM (101) and the working experience of almost one year.

Table 2 shows the knowledge and awareness of HCWs towards the disease caused by needle stick injuries. $98 \%$ of them were aware of the disease HBV, HCV, HIV which can occur due to NSI, but only $60 \%$ could define the HIV properly but 139 of them knew what AIDS is. Of the 152 only $70 \%$ were vaccinated against Hep Band 14 of them did 
not know their vaccinated status whereas only 15 had been tested for antiHbs antibody and 90 of them did not have their anti Hbs checkup while 47 of them were unaware of their antiHbs status.

Table 3 shows the characteristics of the respondents towards NSI. Of the 152 maximum () were gloved, in spite of that 51 of them had NSI but reported incident were less (). Injuries were maximum due to $\mathrm{Im} / \mathrm{Iv}$ injections (55) followed by recapping (50), and 109 were the open bore needles. Circumstances reported by the respondents for the NSI were uncooperative behavior of the patients (60) and rush (55).

Table 4 shows that maximum respondents did not know about the tests and the vaccinations to be taken after NSI as 83 of them had not given the information regarding PEP correctly.
In our study, Of the 152 health care workers, $86 \%$ were aged between 20-30 years and majority of them were females $(86.6 \%)$ and unmarried $(75 \%)$ which is similar to the study done by A R ISARA, RAKESH SHAH and sanjay dixit $(1,6,13)$ where maximum percentage were aged between 19-40 and mostly were females $(56 \%)$.

This finding of more females may be attributed to the fact that higher proportions of $\mathrm{HCW}$ are mostly nurses which is a female dominating profession.

Working duration of maximum number of $\mathrm{HCW}$ in our study was found to be one year as $41 \%$ of them had an experience of less than or exact one year with maximum $(66 \%)$ highest qualification Of GNM. which correlates with study done by Laishram et al., in which the working duration is of 1-5 years $(50 \%)$ and highest qualification of GNM. (2)

Table.1 Demographic characteristic of health care workers $(n=152)$

\begin{tabular}{|l|l|l|}
\hline \multicolumn{2}{|l|}{ Demographic characteristic } & Number (percentage) \\
\hline Age(years) & 131 & $86 \%$ \\
\hline $20-30$ & 10 & $6.6 \%$ \\
\hline $30-40$ & 06 & $4 \%$ \\
\hline $40-50$ & 05 & $3.3 \%$ \\
\hline$>50$ & & \\
\hline Sex & 20 & $13 \%$ \\
\hline Male & 132 & $86.6 \%$ \\
\hline Female & & \\
\hline Duration as health care worker (in years) & 63 & $41 \%$ \\
\hline $0-1$ & 33 & $21 \%$ \\
\hline $1-2$ & 20 & $13 \%$ \\
\hline $2-3$ & 18 & $11.8 \%$ \\
\hline $3-4$ & 08 & $5.3 \%$ \\
\hline $4-5$ & 06 & $4 \%$ \\
\hline $5-10$ & 04 & $2.6 \%$ \\
\hline$>10$ & & \\
\hline Educational Qualification & 101 & $66 \%$ \\
\hline GNM & 21 & $13.8 \%$ \\
\hline BSc. Nursing & 27 & $17.7 \%$ \\
\hline Technician & 03 & $1.9 \%$ \\
\hline MSc. Nursing & & \\
\hline Status & 37 & $24.3 \%$ \\
\hline Married & 115 & $75.6 \%$ \\
\hline Unmarried & & \\
\hline
\end{tabular}


Table.2 Knowledge, attitude of health care workers regarding needle stick injuries

\begin{tabular}{|c|c|c|}
\hline Questions & & Numbers (percentage) \\
\hline Hepatitis B vacc & & \\
\hline Yes & 70 & $46 \%$ \\
\hline No & 68 & $44.7 \%$ \\
\hline Unknown Status & 14 & $9.2 \%$ \\
\hline Anti HBs antibo & & \\
\hline Checked & 15 & $21.4 \%$ \\
\hline Not checked & 55 & $78.5 \%$ \\
\hline What is HIV & & \\
\hline Correct by & 60 & $39.4 \%$ \\
\hline What is AIDS & & \\
\hline Correct by & 139 & $91.4 \%$ \\
\hline $\begin{array}{l}\text { How does HIV s } \\
\text { Sexual contact } \\
\text { Needlestick inju } \\
\text { Blood transfusio } \\
\text { Mother to child }\end{array}$ & & \\
\hline Yes & 133 & $87 \%$ \\
\hline No & 19 & $12.5 \%$ \\
\hline $\begin{array}{l}\text { DOES SEXUAL } \\
\text { INCREASE TH }\end{array}$ & & \\
\hline YES & 135 & $88.8 \%$ \\
\hline $\mathrm{NO}$ & 17 & $11.2 \%$ \\
\hline $\begin{array}{l}\text { CAN A WOMA } \\
\text { THE VIRUS T }\end{array}$ & & \\
\hline Yes & 115 & $75.6 \%$ \\
\hline No & 37 & $24.3 \%$ \\
\hline CAN HIV SPRE & & \\
\hline Yes & 32 & $21 \%$ \\
\hline No & 120 & $78.9 \%$ \\
\hline $\begin{array}{l}\text { CAN HIV SPRE } \\
\text { SHARING CLO }\end{array}$ & & \\
\hline Yes & 22 & $14.4 \%$ \\
\hline No & 130 & $85.5 \%$ \\
\hline $\begin{array}{l}\text { WHO ARE AT } \\
\text { HEALTH CAR } \\
\text { DRUG ADDICT } \\
\text { SEXUAL WOR } \\
\text { BABIES OF IN }\end{array}$ & & \\
\hline Yes & 88 & $57.8 \%$ \\
\hline No & 64 & $42.1 \%$ \\
\hline IS THERE TRE & & \\
\hline Yes & 52 & $34.2 \%$ \\
\hline No & 100 & $65.7 \%$ \\
\hline IS THERE A V & & \\
\hline Yes & 47 & $30.9 \%$ \\
\hline No & 105 & $69 \%$ \\
\hline $\begin{array}{l}\text { IF A MALE IS } \\
\text { HIS FEMALE }\end{array}$ & & \\
\hline Yes & 150 & $98.6 \%$ \\
\hline No & 02 & $1.3 \%$ \\
\hline $\begin{array}{l}\text { WHICH DISEA } \\
\text { NEEDLE STIC } \\
\text { HEPATITIS B } \\
\text { HEPATITIS C } \\
\text { HIV }\end{array}$ & & \\
\hline CORRECT & 98 & $64.4 \%$ \\
\hline WRONG & 54 & $35.5 \%$ \\
\hline
\end{tabular}


Table.3 Characteristics of NSI

\begin{tabular}{|c|c|c|}
\hline \multirow{2}{*}{\multicolumn{2}{|c|}{$\begin{array}{l}\text { Questions } \\
\text { DID YOU EVER HAD NSI }\end{array}$}} & \multirow[t]{2}{*}{ Numbers (percentage) } \\
\hline & & \\
\hline YES & 51 & $33.5 \%$ \\
\hline NO & 101 & $66 \%$ \\
\hline \multicolumn{2}{|c|}{ HAVE YOU REPORTED THE INCIDENT OF NSI } & \\
\hline YES & 40 & $26.3 \%$ \\
\hline NO & 112 & $73.6 \%$ \\
\hline \multicolumn{2}{|c|}{ WHICH ACTIVITY LEAD TO NSI } & \\
\hline $\begin{array}{l}\text { GIVING I/V INJECTION/ } \\
\text { GIVING I/M INJECTION }\end{array}$ & 55 & $36.1 \%$ \\
\hline BLOOD WITHDRAWL & 10 & $6.6 \%$ \\
\hline SUTURING/STITCHING & 27 & $17.7 \%$ \\
\hline RECAPPPING & 50 & $32.8 \%$ \\
\hline OTHERS & 10 & $6.6 \%$ \\
\hline \multicolumn{2}{|c|}{ WERE YOU WEARING GLOVES } & \\
\hline YES & 119 & $78.2 \%$ \\
\hline NO & 33 & $21.7 \%$ \\
\hline \multicolumn{2}{|c|}{ CIRCUMSTANCES WHEN YOU GOT NSI } & \\
\hline DURING RUSH & 55 & $36.1 \%$ \\
\hline UNCOPERATIVE PATIENT & 60 & $39.4 \%$ \\
\hline LACK OF ASSISTANCE & 27 & $17.7 \%$ \\
\hline FATIGUE & 10 & $6.6 \%$ \\
\hline \multicolumn{2}{|c|}{ SHOULD NEEDLE BE RACPPED AFTER USED } & \\
\hline YES & 112 & $73.6 \%$ \\
\hline $\mathrm{NO}$ & 40 & $26.3 \%$ \\
\hline \multicolumn{3}{|c|}{$\begin{array}{l}\text { HOW SHOULD YOU DISPOSE THE NEEDLE AND SYRINGE } \\
\text { CUT THE NEEDLE AND DISPOSE IN BIN } \\
\text { CUT THE NEEDLE AND DISPOSE IN SODIUM HYPOCHLORITE IN SOLUTION } \\
\text { RECAP THE NEEDLE AND DISPOSE }\end{array}$} \\
\hline CORRECT & 129 & $84.8 \%$ \\
\hline WRONG & 23 & $15.1 \%$ \\
\hline \multicolumn{3}{|c|}{ WHICH TYPE OF NEEDLE WAS USED } \\
\hline Open Bore & 109 & $71 \%$ \\
\hline Closed Bore & 43 & $28.2 \%$ \\
\hline
\end{tabular}

Table.4 Knowledge of Respondents towards Post Exposure Prophylaxis

\begin{tabular}{|c|c|c|}
\hline \multirow{2}{*}{\multicolumn{3}{|c|}{$\begin{array}{l}\text { Questions } \\
\text { DO YOU KNOW ABOUT UNIVERSAL PRECAUTIONS GUIDELINE }\end{array}$}} \\
\hline & & \\
\hline YES & 100 & $65.7 \%$ \\
\hline NO & 52 & $34.2 \%$ \\
\hline \multicolumn{3}{|c|}{$\begin{array}{l}\text { IMMEDIATE MEASURES UNDERTAKEN AFTER A NEEDLE STICK INJURY: } \\
\text { WASH WITH WATER } \\
\text { WASH WITH WATER AND SOAP } \\
\text { WASH WITH WATER AND ANTISEPTIC } \\
\text { WASH WITH WATER,SOAP AND APPLY ANTISEPTIC AND PEP }\end{array}$} \\
\hline CORRECT & 93 & $61.1 \%$ \\
\hline WRONG & 59 & $38.8 \%$ \\
\hline \multicolumn{3}{|c|}{ DO YOU KNOW ABOUT POST EXPOSURE PROPHYLAXIS } \\
\hline YES & 69 & $45.3 \%$ \\
\hline NO & 83 & $54.6 \%$ \\
\hline \multicolumn{3}{|c|}{$\begin{array}{l}\text { WHICH BLOOD TEST SHOULD BE DONE AFTER A NEEDLE STICK INJURY } \\
\text { HIV TESTING } \\
\text { HBSAg TESTING } \\
\text { HCV TESTING }\end{array}$} \\
\hline CORRECT & 69 & $45.3 \%$ \\
\hline WRONG & 83 & $54.6 \%$ \\
\hline \multicolumn{3}{|c|}{ WHICH VACCINATION SHOULD BE TAKEN UP AFTER NEEDLE STICK INJURY } \\
\hline HEPATITIS B & 26 & $17.1 \%$ \\
\hline TETANUS TOXOID & 46 & $30.2 \%$ \\
\hline BOTH A AND B & 80 & $52.6 \%$ \\
\hline NONE & 0 & $0 \%$ \\
\hline
\end{tabular}


Concerning about the vaccination $46 \%$ of $\mathrm{HCW}$ were sure for their hepatitis B vaccination while $44.7 \%$ and $9.2 \%$ were neither been vaccinated nor they know their status. Of the 70 subjects only $15(21.4 \%)$ had been tested for anti $\mathrm{Hbs}$ antibodies while $55(78.5 \%)$ did not check their vaccinated response. This correlates with the study of Rakeshshah et al., in which only 12(18\%) were tested for their anti Hbs antibodies out of 67 subjects. (6)

Regarding the knowledge of HCW, $64.4 \%$ were aware of the different diseases caused by needle stick injury. Regardlessly, only $39.4 \%$ could answer what is HIV whereas $91.4 \%$ defined AIDS compeletely. This correlates with the study of sanjay dixit et al., (13) where the situation was same in case of HIV as $24 \%$ of them had answered the full form of it but there is a drastic variation when it comes to AIDS as only $08 \%$ knows its full form. This shows their lack of knowledge and awareness towards medical terminologies. As per the EPINET system, average hospital workers incur approximately 30 NSI per 100 beds per year (14). Therefore, in our study, only $33.5 \%$ had

nsi but $26.3 \%$ had reported the incident which is almost similar to the study of Rakesh Shah et al., (6) In which $36 \%$ had NSI and only $08.3 \%$ had reported the same which is comparatively less as compared to ours whereas the other study by Jalina et al., (2) had mentioned the reporting rate of $43 \%$. This somehow reflects their lack of responsibility towards themselves and unaware of the importance of peps.

Most of the needle stick injuries were caused while doing IM/IV PROCEDURES (36.1\%) and recapping of needle $(32.8 \%)$ in which $78.2 \%$ of HCWs were gloved and 109 used open bore needles. This is in concordance with the study done by Jalina et al., (2) in which $93 \%$ of NSI occurred by open bore and while giving IM/IV and not due to recapping but in contrast studies done by Isara et al., and
Muralidhar et al., $(1,15)$ had mentioned the cause of injury as recapping(38\%)(66.3\%). Now, Circumstances which led to NSI were due to rush 36.1 and uncooperative behaivour of the patients which again correlates with the study of Jalina et al., (2) where $44.1 \%$ incidents were due to rush, $25.6 \%$ uncooperative behaivour but $96.5 \%$ of them were without gloves. Comparatively study done by AR ISARA and RAHUL SHARMA et al., $(1,16)$ had given Aggression $(26 \%)$ and fatigue $(50 \%)$ as the reasons for needle stick injury.

In this study higher proportion of HCWs $65.7 \%$ were very well aware of the Universal precautions guidelines and the immediate measures to be taken after needle stick injury $(61 \%)$ but talking about the post exposure prophalyxis (pep), 54.6\% did not know about it that accounts for more than half of the population. Maximum respondents were unaware of the tests and vaccination post injury as $54.6 \%$ and $52.6 \%$ of them had not described it correctly. This is in concordance with the study undertaken by A R ISARA (1) where they have also mentioned the low (22\%) uptake of PEP. This reflects the ignorance and negligence behaivour of HCWs. Another study by Jalina (2) had also reported the same that $94.3 \%$ of HCWs especially nurses did not took PEPs.

In conclusion, our study reflects the high occurrence of needle stick injuries among the health care workers due to their negligence towards the universal work precautions and unawareness about the post exposure prophylaxis. We also came out to the conclusion of the poor knowledge among HCWs concerning the medical terms. Therefore through this study, we would like to emphasize on the facts of creating or organizing more workshops / lectures for the HCWs which can cover-up all the important universal guidelines, medical terminologies and update on every aspect of health of the HCWs and the patients been treated under them. 


\section{References}

Isara AR, Oquzie KE, Okpogoro OE. Prevalence of needlestick injuries among healthcare workers in the accident and emergency department of a teaching hospital in Nigeria. Ann Med Health Sci Res., 2015; 5(6):392-96.

Jalina L, avinash $\mathrm{K}$, Ebenezer $\mathrm{P}$, et al., prevalence of needle stick injuries among nurses in a tertiary care hospital and their immediate response. International $J$ Med and Public Health 2013; 3(4):256-60.

Mihir G, Parul P, Sunil N,H.K. Mehta, et al., Needle Stick And Sharp Instruments Injuries Among Health Care Providers At Cardiology Institute, Ahmedabad. National Journal of Community Medicine, 2010; 1(2).

Centres for Disease Control and Prevention. Preventing Needle stick Injuries in Healthcare Settings. [Last accessed on 2015 Feb 20].

Muralidhar S, Singh PK, Jain RK, Malthotra M, Bala M. Needle stick injuries among health care workers in a tertiary care hospital of India. Indian J Med Res. 2010; 131:405-10.

Rakesh Shah, H.K. Mehta, Manish Fancy, et al., Knowledge and Awareness Regarding Needle Stick Injuries among Health Care Workers in Tertiary Care Hospital in Ahmedabad, Gujrat. National J Comm Med 2010; 1(2):93-96.

Calver J. Occupational Health Services. Am J Infect Control 1997; 25:363-5?

ICN on preventing needle stick injuries. Nursing matters: Fact sheets 2009.

Cardo DM, Culver DH, Ciesielski CA, Srivastava PU, Marcus R, Abiteboul D, et al., A case-control study of HIV seroconversion in health care workers after percutaneous exposure. Centers for disease control and prevention needle stick surveillance group. $N$ Engl $\mathrm{J} \mathrm{Med}$ 1997; 337:1485-90.

Ippolito G, Puro V, Heptonstall J, Jagger J, De Carli G, Petrosillo N. Occupational human immunodeficiency virus infection in health care workers: Worldwide cases through September 1997. Clin Infect Dis, 1999; 28:365-83.

Sarrazin U, Brodt HR, Sarrazin C, Zeuzem S. Prophylaxis against HBV, HCV and HIV after occupational exposure. Dtsch Arztebl 2005; 102:2234-39.

World Health Organization, the World Health Report, Box 4.4. 2002. Geneva, Switzerland.

Sanjay Dixit, Khatri AK, Gunjan Taneja, et al., Impact of Educational Intervention Measures on Knowledge regarding HIV/ Occupational Exposure and Post Exposure Prophylaxis among Final Year Nursing Students of a Tertiary Care Hospital in Central India. Journal of Health and Allied Sciences: 2009; 4(8)

EPINet, Exposure Prevention Information Network data reports. University of Virginia: International Health Care Worker Safety Center.

Muralidhar S, Prashant KS, RK Jain, et al., Needle Stick Injuries among Health Care Workers in a tertiary care hospital of India. Indian J Med Res 2010; 131: 40510.

Rahul Sharma, SK Rasania, Anita Verma, Saudan Singh. Study of Prevalence and Response to Needle Stick.

Injuries among Health Care Workers in a Tertiary Care Hospital in Delhi, India. Indian Journal of Community Medicine. 2010: 1(35).

Nikhil Gupta, Binita Goswami, Bhawna Singh, Sandeep Ghosh. Awareness about HIV infection among the paramedical staff in a tertiary care hospital in Delhi, India. Clinics and Practice 2012; 2: e13.

\section{How to cite this article:}

Amisha Sharma, Charu Singh, Seema Solanki, Satishkumar, Priya Mehrishi and Sameer Singh Faujdar. 2017. Prevalence and Knowledge of Needle Stick Injury among the Health Care Workers in a Tertiary Care Hospital Solan H.P, India Int.J.Curr.Microbiol.App.Sci. 6(8): 2486-2492. doi: https://doi.org/10.20546/ijcmas.2017.608.294 